\title{
Characterization of Blendok Disease (Botryodiplodia theobromae Pat.) on Pummelo (Citrus grandis L. Osbeck) in Bali
}

\author{
Ida Bagus Komang Mahardika ${ }^{{ }^{*}}$, Anak Agung Sagung Putri Risa Andriani², Luh \\ Komang Sulasmini Mudra ${ }^{3}$ \\ ${ }^{1,2,3}$ Universitas Warmadewa, Denpasar-Bali, Indonesia \\ \{gusmahardika62@gmail.com¹,putri_risa69@yahoo.com², 1ksulasmini66@gmail.com³
}

\begin{abstract}
Pummelo in Balinese speaking is called Jerungga, Jeruti, Muntis, Juuk Saba, Juuk Bona or Juuk Gede. Morphologically and genetically, pummelo in Bali is known to be 5 (five) types of cultivars. The main cause of the decline in the population of pummelo plants in Bali is due to infection with blendok disease caused by the fungus Botryodiplodia theobromae Path. Characterization of the pathogen causing blendok disease is needed to determine the characteristics and pathogenicity of the fungus in pummelo plants. This is useful for determining how to control it effectively. The results showed that the pathogen of blendok disease in Bali was the fungus Botryodiplodia theobromae which had a gray color in the early stages of growth. This fungus has a shape like cotton and has abundant air between the micelles. The conidium is oval, one insulated, dark in color and the exospores have pathways. On the first day, the area of B. theobromae colonies was $1.13 \mathrm{~cm} 2$. Furthermore, on the second day to the fifth day experienced a rapid growth rate that reached $75.46 \mathrm{~cm} 2$. Growth rate, the fungus B. theobromae grows faster than the control fungus which is often referred to as the biological agent Trichoderma atroviride and Gliocladium sp.
\end{abstract}

Keywords: Citrus grandis L. Osbeck; Blendok Disease; Botryodiplodia theobromae Pat.

\section{Introduction}

Pummelo (Citrus grandis L. Osbeck) is a native citrus originating from Indonesia and spread from Polynesia to Malacca which has various names according to the region. The names in each area for this type of citrus vary, namely: jeruk Pandan, jeruk Srinyonya, jeruk Cikoneng, jeruk Nambangan, jeruk Pomegranate, jeruk Silempang, jeruk Oyod Gondong, jeruk Nambangan-Madiun, jeruk bali, jeruk Pandanwangi. Pummelo in Balinese speaking is called Jerungga, Jeruti, Muntis, Juuk Saba, Juuk Bona or Juuk Gede. This orange is a species of citrus whose fruit is the largest which has thick skin and large pulp. Pummelo is usually cultivated in the Balinese yard as a yard fruit plant that has fragrant flowers so that the yard becomes fresher. Pummelo has many health benefits, both as a source of vitamins and for the purposes of healing several diseases. Also the leaves, bark and flowers are widely used for medicinal and cosmetic purposes [1]-[3].

The main cause of the decline in the population of pummelo (Citrus grandis L. Osbeck) in Bali is due to the fact that most of the plants are infected with blendok disease caused by the 
fungus Botryodiplodia theobromae Pat [4], [5]. This pathogenic infection causes sores on the skin of the pummelo plant and the appearance of a yellow liquid which will harden over time so that it forms crystals with a brownish yellow color. Symptoms of this disease are called gumosis and the discharge in the form of mucus is called gum. Gumosis is the response of citrus plants to infection from pathogens on infected plant stems [6]-[8].

Based on the description above, a study was conducted to determine the characteristics of the pathogenic fungus Botryodiplodia theobromae which is a pathogen for blendok disease in pummelo in Bali, both in vitro and on pummelo plants in the field, in order to learn how to overcome it in pummelo plantations.

\section{Methodology}

This research will be carried out at the location of the pummelo plantation in the Carangsari area, Badung regency, where there are plants that have symptoms of blendok disease. Subsequently identified at the Laboratory for the Protection of Food Crops and Horticulture, Bali Province, starting from March to November 2020.

The research was conducted with an exploration method for the cause of blendok disease in the pummelo plantation area with the aim of obtaining more knowledge (about the situation), especially the natural resources found in that place. Exploration of the fungus Botryodiplodia theobromae taken from the skin or stem of the pummelo plant that is infected. The samples were then isolated in vitro in a petridish to be identified in detail, both morphology and development. Next is also compared with the performance of biological agent fungi that are planned as materials for the control of these pathogens.

The tools used in this study were plastic samples, scales, petridishes, erlenmeyer tubes, test tubes, bunsen, laminar air flow, measuring cups, ent needles, dropper pipettes, aluminum foil, plastic wrap, label paper, trays, jars, cloth. gauze, heat-resistant plastics, autoclaves, cameras, scales and stationery. The materials used in this study were soil samples from the rhizosphere of rice and citrus plants, plant skin attacked by B. theobromae, Potato Dextrose Agar (PDA), potato, agar, sucrose, $70 \%$ alcohol, distilled water and antibiotics (Chloramphenicol).

The exploration of $B$. theobromae fungi was carried out on the skin or stem of the pummelo plant. The sample is taken then put into a container and separated between the container for the infected skin and the infected stem.

Isolation is a way to separate or move microorganisms to be purified to make isolates. Before you can make isolates, purification needs to be done so that the mushrooms to be purified are not contaminated by other fungi. Purification is carried out in order to obtain target mushrooms that have been previously selected for the purpose of facilitating the manufacture of isolates. Fungi that are explored in petridish will grow various types of fungi that have previously existed in the soil that have been explored. Microorganisms on the soil that will be explored will grow various types of fungi, fungi that grow in the form of pathogenic fungi, fungi with biological control agents and decomposer fungi which have various types. Purification is an activity to obtain pure colonies of previously grown microorganisms. Purification is carried out by moving some of the microorganism colonies into a new growth medium so that the expected pure colonies can be obtained. The method used is the strict method by taking $B$. theobromae mushrooms using a round loop needle. This method will be repeated until it produces pure $B$. theobromae mushrooms. 
Isolate is a pure culture of a microorganism from its original source. Making Botryodiplodia theobromae isolates is by taking the fungus, then inoculating it on the media that has been provided. The steps for making isolates are to prepare the medium for the isolates, namely PSA (Potato Sucrose Agar) media. Furthermore, PSA media is put in a test tube or bottle that is heat and pressure resistant, then sterilized using an autoclave at a temperature of $1210 \mathrm{C}$ with a pressure of 105 Pascal.

The observed variables are:

1) Morphology and characteristics of pathogenic fungi in vitro

2) Area of pathogenic colonies

3) Growth rate of pathogens

4) Microscopic identification of pathogenic characteristics

Observation of the size and characteristics of pathogens and identify their suitability with existing references. The data obtained were then analyzed descriptively and with statistical programs.

\section{Result And Discussion}

\subsection{Identification of blendok Botryodiplodia theobromae mushroom isolate}

The morphology of B. therobroma fungi isolates has a gray color in the early stages of growth. This fungus has a shape like cotton and has abundant air between the micelles (Figure 1). The conidium is oval, single-insulated, dark in color and the exospores have stripes.

(a)

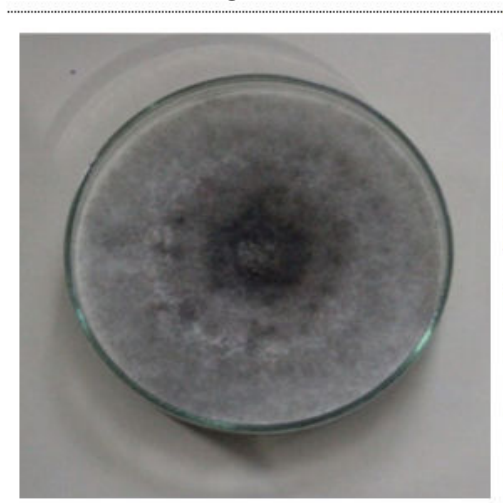

h
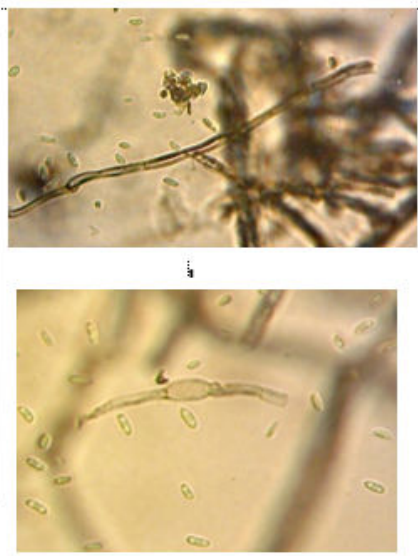

(b)

(c)

Figure 1. Botryodiplodia theobromae isolate ; (a) Koloni on PDA, (b) Hifa, (c) Konidia

\subsection{Identification of control fungal isolates Trichoderma sp. and Gliocladium sp.}

Comparison mushroom isolate Trichoderma $\mathrm{sp}$. it has a round colony shape, has a slightly yellowish green color and white micelles (Figure 2). Conidiophores are unilateral and usually paired. The form of fialides is straight or tortuous, cylindrical, narrow at the end of the fialides and has oval-shaped conidia [9]. 
(a)

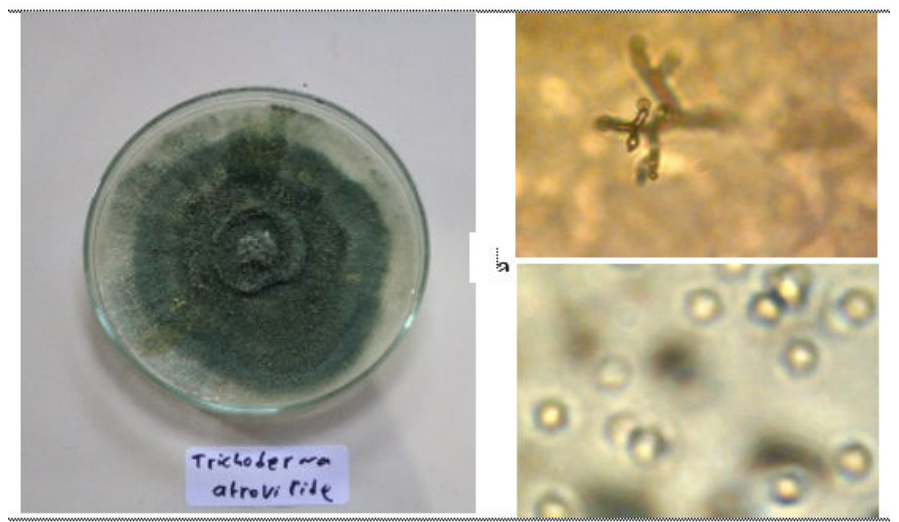

(b)

(c)

Figure 2. Morphology of Trichoderma sp. (a) Colonies on PDA, (b) form fialides and (c) form conidia

Morphology of Gliocladium sp. has a colony of green spots on the spores (Figure 3). Conidiophores with septa and brush-shaped fialides similar to Penicillium $s p$. The apex is branched and perpendicular, conidia appear on the primary branches and are oval in shape [10].

(a)

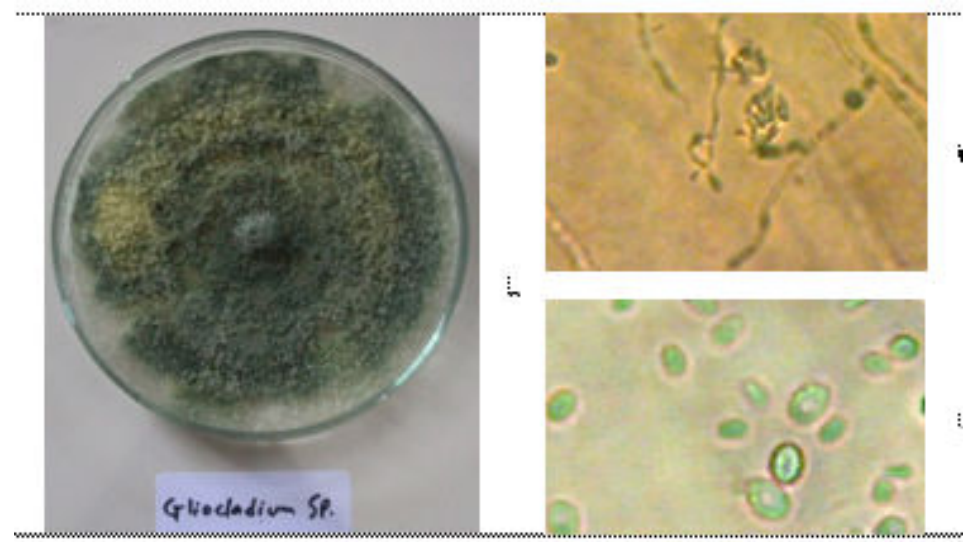

(b)

(c)

Figure 3. Morphology of Gliocladium sp (a) Colony on PDA, (b) Form of fialides, (c) Form of conidia

\subsection{Growth rate}

On the first day, the colony area of $B$. theobromae and $T$. atroviride was $1.13 \mathrm{~cm} 2$, while Gliocladium $s p$. As big as $0.79 \mathrm{~cm} 2$. Furthermore, on the second to the fifth day B. theobromae experienced a rapid growth rate and on the fifth day almost all of the petri dishes were covered, namely $75.46 \mathrm{~cm} 2$. For the area of $B$. theobromae colonies experienced a very fast growth rate beating $T$. atroviride on the third and fourth days. The growth of the fungus Gliocladium sp. reduced on the fifth day. On the fifth day, the difference in the growth of Gliocladium sp. with the other two mushrooms is $3.04 \mathrm{~cm} 2$ (Table 1; Figure 4.). 
Table 1. Colony growth rate

\begin{tabular}{cccc}
\hline \multirow{2}{*}{ Days } & \multicolumn{3}{c}{ Colony Area $\left(\mathrm{cm}^{2}\right)$} \\
\cline { 2 - 4 } & T. atroviride & Gliocladium sp. & B. theobromae \\
\hline 1 & 1.13 & 0.79 & 1.13 \\
2 & 5.72 & 4.91 & 16.61 \\
3 & 22.89 & 28.26 & 54.08 \\
4 & 48.99 & 60.79 & 75.46 \\
5 & 78.50 & 75.46 & 78.50 \\
\hline
\end{tabular}

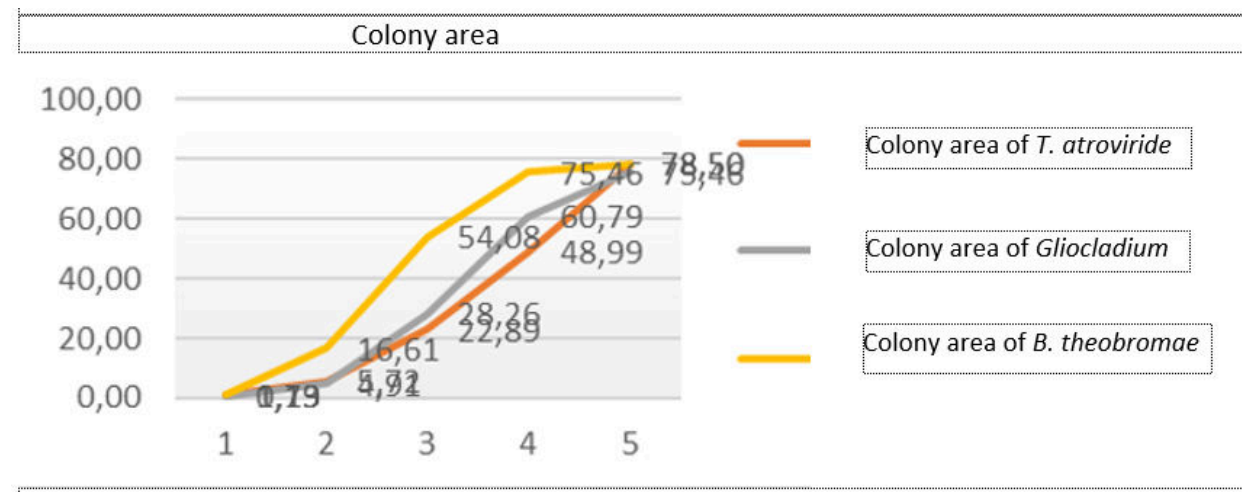

Figure 4. The growth rate of $B$. Therobroma and its comparison fungi colonies

The morphology of the isolate that causes blendok disease on pummelo in Bali is identical to that of Botryodiplodia theobromae, which has a gray color in its early growth phase. This fungus has a shape like cotton and has abundant air between the micelles. The conidium is oval, single-insulated, dark in color and the exospores have stripes. Based on previous information, pathogenic fungi such as B. therobroma can be suppressed by utilizing other fungi that have been proven to be used as biological agents. So that control efforts can be tried by utilizing antagonistic fungi which are not pathogens for pummelo plants as their hosts. Likewise, control fungi, which are non-pathogenic fungi in the host plant such as oranges in general, namely Trichoderma atroviride and Gliocladium sp, also have characteristics in accordance with existing references When viewed from the growth rate, Botryodiplodia theobromae filled the petri dish the fastest compared to comparison fungi, namely Trichoderma atroviride and Gliocladium sp.. Botryodiplodia theobromae fungi grow faster in the early phase, beating the control fungi which are often referred to as biological agents. On the second to fourth days Botryodiplodia theobromae grew faster than the two antagonistic fungi. On the fifth day, B. theobromae and T. atroviride filled the petri dishes. Meanwhile, Gliocladium $s p$. grow slower and only fill the petridish on the sixth day. However, it is necessary to try to test the compressive power of the biological agent fungus against the fungus that causes this blendok disease, as an effort to utilize biological agents that are indispensable in controlling plant diseases by minimizing the use of chemical pesticides that are harmful to the environment. 
Fungus which are biological agents such as. and Trichoderma atroviride can be used as a control for pathogenic fungi such as $B$. theobromae because these antagonistic fungi are able to produce compounds or enzymes capable of parasitizing pathogenic fungi. Hyphae Trichoderma spp. Can produce chitinase, glucanase and protease enzymes which can degrade the host hyphae during parasitism, while Gliocladium sp. produce glyotoxins that can inhibit the growth of pathogenic fungal mycelia [11].

\section{Conclusions And Sugestions}

\subsection{Conclusion}

Based on the results and discussion of this research, the following conclusions can be drawn :

1. The pathogen of blendok disease in Bali is the fungus Botryodiplodia theobromae which has a gray color in the early stages of it's growth. This fungus has a shape like cotton and has abundant air between the micelles. The conidium is oval, one insulated, dark in color and the exospores have pathways.

2. On the first day, the area of B. theobromae colonies was $1.13 \mathrm{~cm} 2$. Furthermore, on the second day to the fifth day experienced a rapid growth rate that reached 75.46 $\mathrm{cm} 2$.

3. Growth rate of Botryodiplodia theobromae fungi grow faster than comparison fungi which are often referred to as biological agents Trichoderma atroviride and Gliocladium sp.

\subsection{Suggestions}

Further research is needed to test the antagonism of fungi that have the ability to suppress the growth of the pathogenic fungus Botryodiplodia theobromae but without causing disease in host plants, such as the species Trichoderma sp. and Gliocladium sp.

\section{Acknowledgments.}

We thank the University Warmadewa through Warmadewa University Research Institute on the funding of this research so that it can take place properly.

\section{References}

[1] B. A. Arias and L. Ramón-Laca, "Pharmacological properties of citrus and their ancient and medieval uses in the Mediterranean region.," J. Ethnopharmacol., vol. 97, no. 1, pp. 89-95, 2005.

[2] A. Chaidedgumjorn, U. Sotanaphun, N. Kitcharoen, P. Asavapichayont, M. Satiraphan, and P. Sriamornsak, "Pectins from Citrus maxima," Pharm. Biol., vol. 47, no. 6, pp. 521-526, 2009.

[3] A. Oyedepot and S. O. Babarinde, "Effects of shaddock (Citrus maxima) fruit juice on glucose tolerance and lipid profile in type-II diabetic rats," Chem Sci Trans, vol. 2, 
no. 1, pp. 19-24, 2013.

[4] S. K. Ogundana, "Life cycle of Botryodiplodia theobromae, a soft rot pathogen of yam," J. Phytopathol., vol. 106, no. 3, pp. 204-213, 1983.

[5] I. B. K. Mahardika, I. N. Rai, M. S. Mahendra, and R. Dwiyani, "Genetic Diversity and Fruit Quality of Several Pomelo 'Jeruk Bali'(Citrus grandis L. Osbeck) Cultivars in Bali.," Int. J. Biosci. Biotechnol., vol. 5, no. 1, pp. 43-59, 2017.

[6] Meliola, Pengantar Ilmu Penyakit Tumbuhan. Yogyakarta: Gajah Mada University Press, 2009.

[7] N. P. Mohapatra, S. P. Pati, and R. C. Ray, "In vitro inhibition of Botryodiplodia theobromae (Pat.) causing Java black rot in sweetpotato by phenolic compounds," Ann. Plant Prot. Sci., vol. 8, no. 1, pp. 106-109, 2000.

[8] A. E. Marpaung, F. H. Silalahi, and E. I. Y. Purba, "Identifikasi Patogen Penyebab Busuk Pangkal Batang pada Tanaman Jeruk di Tanah Karo," J. Hortik., vol. 20, no. 3, 2013.

[9] I. S. Druzhinina et al., "Trichoderma: the genomics of opportunistic success," Nat. Rev. Microbiol., vol. 9, no. 10, pp. 749-759, 2011.

[10] S. V Gil, S. Pastor, and G. J. March, "Quantitative isolation of biocontrol agents Trichoderma spp., Gliocladium spp. and actinomycetes from soil with culture media," Microbiol. Res., vol. 164, no. 2, pp. 196-205, 2009.

[11] H. S. Khairani, M. S. Sinaga, and K. H. Mutaqin, "Mekanisme pengendalian penyakit busuk batang jeruk oleh khamir, kitosan, cendawan mikoriza arbuskular, dan bakteri simbiotiknya,” J. Fitopatol. Indones., vol. 13, no. 1, p. 17, 2017. 